\title{
Assessment of Groundwater Pollution with Heavy Metals in North West Bank/Palestine by ICP-MS
}

\author{
Husam Malassa ${ }^{1,2}$, Mohamad Hadidoun ${ }^{3}$, Mahmoud Al-Khatib ${ }^{4}$, Fuad Al-Rimawi ${ }^{4}$, \\ Mutaz Al-Qutob ${ }^{1,2^{*}}$ \\ ${ }^{1}$ Department of Earth and Environmental studies, Faculty of Science and Technology, Al-Quds University, East Jerusalem, Palestine; \\ ${ }^{2}$ Aquatic and Aquaculture Research Laboratory, Al-Quds University, East Jerusalem, Palestine; ${ }^{3}$ Palestinian Water Authority, Ra- \\ mallah, Palestine; ${ }^{4}$ Faculty of Science and Technology, Al-Quds University, East Jerusalem, Palestine. \\ Email: *qutob@planet.edu
}

Received November $21^{\text {st }}$, 2013; revised December $18^{\text {th }}$, 2013; accepted January $6^{\text {th }}, 2014$

Copyright (C 2014 Husam Malassa et al. This is an open access article distributed under the Creative Commons Attribution License, which permits unrestricted use, distribution, and reproduction in any medium, provided the original work is properly cited. In accordance of the Creative Commons Attribution License all Copyrights @ 2014 are reserved for SCIRP and the owner of the intellectual property Husam Malassa et al. All Copyright (C) 2014 are guarded by law and by SCIRP as a guardian.

\section{ABSTRACT}

Groundwater of North West Bank in Palestine was assessed for pollution with trace metals by ICP/MS. The samples were analysed for their $\mathrm{pH}$, electrical conductivity, total dissolved solids, and different trace metals content. The $\mathrm{pH}$, electrical conductivity, and total dissolved solids of all water samples were found to be within the US Environmental protection Agency limits. Results showed that the concentration of nine trace metals $(\mathrm{Cr}, \mathrm{Mn}$, $\mathrm{Ni}, \mathrm{Cu}, \mathrm{Zn}, \mathrm{Mo}, \mathrm{Pb}, \mathrm{Cd}$, and $\mathrm{Al})$ is within the WHO limits in drinking water $(50,500,20,2000,3000,70,10,3$, and $200 \mathrm{ug} / \mathrm{L}$, respectively), however six metals of them $(\mathrm{Cr}, \mathrm{Mn}, \mathrm{Ni}, \mathrm{Cu}, \mathrm{Mo}$, and $\mathrm{Al}$ ) were detected in $100 \%$ of the samples, while $\mathrm{Pb}, \mathrm{Cd}$, and $\mathrm{Zn}$ were detected in $80 \%, 60 \%$, and $20 \%$ of the samples, respectively. On the other hand, Tl which is a very toxic heavy metal with allowed WHO limits of $0.01-1 \mathrm{ug} / \mathrm{L}$ is detected in $100 \%$ of the water samples analysed with a range of $0.02-0.12 \mathrm{ug} / \mathrm{L}$. It indicates that such concentration levels of Tl would be harmful to the human being drinking the water. In general, $82 \%$ of all samples analysed contained one or more of the 12 metals studied each in varying concentration. Results of this study suggest a possible risk to the people of the study area given the toxicity of heavy metals, and the fact that for many people in the study area, groundwater is a main source of their water supply.

\section{KEYWORDS}

Heavy Metals; Ground Water; Palestine; Pollution; ICP-MS

\section{Introduction}

Heavy metals in groundwater are toxic even at low concentrations [1-3]. Human activities have increased the concentrations of heavy metals in the environment. For example, industry, agriculture, and solid waste disposal increase the contents of heavy metals in water, soil, air, fruits, vegetables, fish, etc. [4-6].

There are 35 metals that concern us because of occupational or residential exposure, of which 23 are heavy metals: antimony, arsenic, bismuth, cadmium, cerium, chromium, cobalt, copper, gallium, gold, iron, lead, manganese, mercury, nickel, platinum, silver, tellurium,

\footnotetext{
"Corresponding author.
}

thallium, tin, uranium, vanadium, and zinc [7]. Although small amounts of these are common in our environment and diet and some are necessary for good health, large amounts of any of them may cause acute or chronic toxicity.

Health risks of heavy metals include reduced growth and development, cancer, organ damage, nervous system damage, and in extreme cases, death. Exposure to some metals, such as mercury and lead, may also lead to autoimmunity. Heavy metals become toxic when they are not metabolized by the body and accumulate in the soft tissues. As noted above, heavy metals may enter the human body via food, water, air, or absorption through the skin in agriculture, industrial, or residential settings [8,9]. 
Many studies have investigated the occurrence and monitoring of heavy metals in groundwater and drinking water. Momodu and Anyakora [1] have assessed groundwater contamination with heavy metals $(\mathrm{Pb}$, and $\mathrm{Cd})$ and Aluminum in Nigeria. The results show that there is a significant risk for the population from drinking groundwater; $\mathrm{Pb}$ and $\mathrm{Cd}$ were detected in $98 \%$ of water samples analysed in that study. Laniyan et al. [10] as well as Oyeku and Eludoyin [11] also investigated the occurrence of heavy metals in groundwater in Nigeria. Momot and Synzynys [12] have investigated toxic aluminium and heavy metals in groundwater of middle Russia and have detected some heavy metals ( $\mathrm{Hg}, \mathrm{Cr}$, and $\mathrm{As}$ ) there. Batayneh [4] has studied heavy metal content in water springs of the Yarmouk Basin (Jordan) and has shown that the Basin is contaminated with heavy metals that might affect human health as well as the health of the ecosystem. Iqbal and Gupta [13] and Rajappa [14] have studied the heavy metal pollution of groundwater in India, and have detected some heavy metals in groundwater samples. Gutierrez et al. [15] have studied the occurrence of heavy metals in water of San Petro River in Mexico and have found that the San Pedro River is contaminated with heavy metals and other contaminants that might affect human health as well as the health of the ecosystem. Kar et al. [16] have studied the assessment of heavy metals pollution in the surface water of the River Ganges in West Bengal. The results show that the dominance of various heavy metals in those waters followed the sequence: $\mathrm{Fe}>\mathrm{Mn}>\mathrm{Ni}>\mathrm{Cr}>\mathrm{Pb}>\mathrm{Zn}>\mathrm{Cu}>\mathrm{Cd}$. Voica et al. [17] have determined different heavy metals in surface water from Transylvania/Romania. The results showed that toxic heavy metals were detected in water samples in the range of few ug/L. Ismail and Mat Saleh [18] have analysed different heavy metals in water samples from Malaysia. Their results showed that the concentrations of heavy metals in water samples were below the detection limit. It is obvious from this literature that studies on the occurrence and determination of heavy metals in water (ground, drinking, surface etc) is an important issue for the human health and for the environment. In Palestine, the principal water resources available include groundwater, springs, and harvested rainwater [19]. However, there are few studies in Palestine that dealt with pollution of groundwater with different pollutants e.g. pesticides, nitrates, chlorides, heavy metals. A study by Ghanem and Samhan [20] has focused on the assessment of pollution of groundwater in Tulkarem area with nitrate and chloride. Their results had indicated that there are many samples with nitrate concentrations exceeding the WHO standards of $45 \mathrm{mg} / \mathrm{L}$ for drinking water. Ghanem et al. [21] have also investigated the groundwater pollution due to pesticides and heavy metals in North West Bank. The results show that $\mathrm{Pb}, \mathrm{Cd}$, and Cr were detected in the groundwater of North West Bank.
The concentration of $\mathrm{Pb}$ was found higher that the WHO limit. El-Nahhal [22] has studied the contamination of groundwater with heavy metals in Gaza Strip. The results showed that the concentration of $\mathrm{Cd}, \mathrm{Pb}, \mathrm{Fe}$, and $\mathrm{Cr}$ are above the EPA limits in some wells.

The objectives of the current study are to study the occurrence of different trace metals ( $\mathrm{Tl}, \mathrm{Pb}, \mathrm{Cr}, \mathrm{Mn}, \mathrm{Co}$, $\mathrm{Ni}, \mathrm{Cu}, \mathrm{Zn}, \mathrm{Mo}, \mathrm{Ag}$, and $\mathrm{Cd}$ ) and $\mathrm{Al}$ in groundwater of North West Bank in order to assess its pollution with metals, as groundwater in the study area is used for drinking.

\section{Experimental}

\subsection{Study Area}

\subsubsection{Climate}

The climate in the West Bank can be characterized as hot and dry during the summer and cool and wet in winter [19]. The climate becomes more arid to the east and south. Evaporation is high in summer when there is always a water deficit. The average annual rainfall in the central highlands is $700 \mathrm{~mm}$ and becomes less than 100 $\mathrm{mm}$ near the Dead Sea. However, great variations in rainfall amounts and distribution exist [19].

\subsubsection{Groundwater: Aquifers and Wells}

The principal water resources available to Palestinians include groundwater, springs, and harvested rainwater [20]. Both groundwater and surface water drain either westwards to the Mediterranean or eastwards to the Jordan River and Dead Sea. The lower Jordan River flows southwards at the eastern edge of the West Bank from Lake Tiberias to the Dead Sea [23]. The West Bank lies over the Mountain aquifer. The Mountain aquifer is divided into the eastern aquifer, the north eastern aquifer, and the western aquifer. The eastern aquifer and part of the north eastern aquifer flow east towards the Jordan River. The western aquifer and part of the north eastern aquifer flow westerly towards the Mediterranean Sea [24, 25].

\subsubsection{Geography and Geology}

North of West Bank including Nablus and Jenin have a highly varying topography and altitude, with the highest point at $940 \mathrm{~m}$ above sea level and the lowest at $150 \mathrm{~m}$ above sea level for Nablus. The same goes for Jenin that has a peak height of $750 \mathrm{~m}$ above sea level while the lowest level is at $90 \mathrm{~m}$ above sea level. In terms of geology, the majority of the Nablus and Jenin area is rocky mainly comprised of carbonate sediment such as limestone, carbonate, chalk and marl. The geological rock age formations range from Cretaceous to Eocene [19].

\subsection{Sampling and Analysis}

Five groundwater wells which are used for drinking were 
selected as representative wells of the study area. Figure 1 shows location of the wells in the study area that were analysed in this study. Three samples were obtained from each well at different times. A total of 15 water samples were collected from the five wells. The water samples were collected in 1-liter high density polyethylene bottles (pre-cleaned with $10 \%$ nitric acid followed by repeated rinsing with bi-distilled water). The collected samples have been stabilized with ultrapure nitric acid $(0.5 \%$ $\mathrm{HNO}_{3}$ ), preserved in a cool place (about $4^{\circ} \mathrm{C}$ ) and transported to the lab of Al-Quds University for further analysis. $\mathrm{pH}$, electrical conductivity, and total dissolved solids were measured in the lab immediately after the arrival of the samples according to standard methods [26]. The samples were then analysed for the following metals ( $\mathrm{Tl}$, $\mathrm{Pb}, \mathrm{Cr}, \mathrm{Mn}, \mathrm{Co}, \mathrm{Ni}, \mathrm{Cu}, \mathrm{Zn}, \mathrm{Mo}, \mathrm{Ag}, \mathrm{Cd}$, and $\mathrm{Al}$ ) which are dissolved in water by ICP/MS (Agilent technologies 7500 series).

For accurate quantitative determination of heavy metals in water samples, an internal standard method was used using $\mathrm{Nd}$ as internal standard and a multi-standard calibration method: (22 metals standard (Ag $10 \mathrm{mg} / \mathrm{L}, \mathrm{Al}$ $50 \mathrm{mg} / \mathrm{L}$, B $50 \mathrm{mg} / \mathrm{L}$, Ba $10 \mathrm{mg} / \mathrm{L}$, Bi $100 \mathrm{mg} / \mathrm{L}$, Ca 10 $\mathrm{mg} / \mathrm{L}$, Cd $10 \mathrm{mg} / \mathrm{L}$, Co $10 \mathrm{mg} / \mathrm{L}$, Cr $50 \mathrm{mg} / \mathrm{L}, \mathrm{Cu} 10$ $\mathrm{mg} / \mathrm{L}$, Fe $10 \mathrm{mg} / \mathrm{L}, \mathrm{K} 100 \mathrm{mg} / \mathrm{L}$, Li $50 \mathrm{mg} / \mathrm{L}, \mathrm{Mg} 10$ $\mathrm{mg} / \mathrm{L}$, Mn $10 \mathrm{mg} / \mathrm{L}$, Mo $50 \mathrm{mg} / \mathrm{L}$, Na $50 \mathrm{mg} / \mathrm{L}$, Ni 50 $\mathrm{mg} / \mathrm{L}, \mathrm{Pb} 100 \mathrm{mg} / \mathrm{L}$, Sr $10 \mathrm{mg} / \mathrm{L}$, Tl $50 \mathrm{mg} / \mathrm{L}$, Zn 10 $\mathrm{mg} / \mathrm{L}$, matrix $5 \% \mathrm{HNO}_{3}$ ). Samples were prepared by dilution of $1.0 \mathrm{~mL}$ of the water samples to $10.0 \mathrm{~mL}$ with $0.3 \%$ ultrapure nitric acid and analysed by ICP/MS. Each sample was analysed three times and the results are expressed as mean \pm SD (SD: standard deviation). Relative standard deviation (RSD) of the three results are calculated and found to be less than $5 \%$ for all samples for all metals analysed in this study, reflecting the precision of

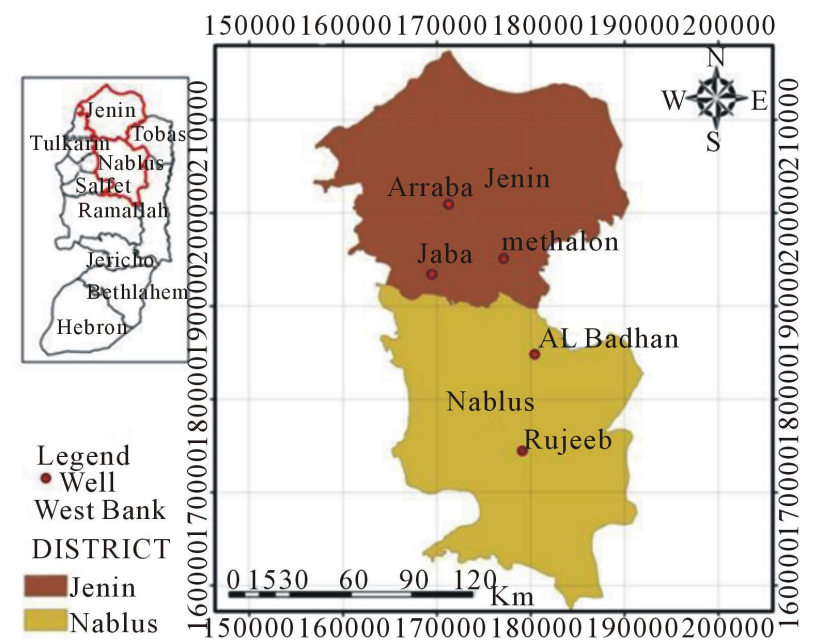

Figure 1. Map of West Bank and the study area showing location of the ground wells analyzed in this study (Arabba, Jaba, Al Badhan, Rujeeb, and Methalon). the method for the analysis of these heavy metals. Calibration curves for all metals analysed were constructed by plotting the ratio of the intensity of the analyse metal to that of the internal standard (Nd) vs. concentration of the trace metal (in ug/L), and results showed that the calibration curves are linear with correlation coefficient $\left(r^{2}\right)$ greater than 0.999 for the trace metals analysed.

\section{Results and Discussion}

This study was conducted to investigate the quality of groundwater which is domestic wells used for drinking in the study area. The people of the study area depend mainly on the groundwater and on the rain water harvested and stored in cisterns or wells. The $\mathrm{pH}$ of all water samples ranged between $6.9-7.8$ which is within the allowed WHO limit (6.5 - 8.5). Electrical conductivity and total dissolved solids of all water samples ranged from 394 - $1432 \mu \mathrm{S} / \mathrm{cm}$, and 225.0 - $816.0 \mathrm{mg} / \mathrm{L}$ respectively. The limit for total dissolved solids in drinking water according to WHO is $1000 \mathrm{mg} / \mathrm{L}$ [27], where our results showed that all water samples are within this limit.

\subsection{Heavy Metals Content}

Results showed that eleven heavy metals ( $\mathrm{Tl}, \mathrm{Pb}, \mathrm{Cr}, \mathrm{Mn}$, concentration of $\mathrm{Tl}, \mathrm{Pb}, \mathrm{Al}, \mathrm{Cr}, \mathrm{Mn}, \mathrm{Co}, \mathrm{Ni}, \mathrm{Cu}, \mathrm{Zn}, \mathrm{Mo}$, $\mathrm{Ag}$, and $\mathrm{Cd}$ ), and $\mathrm{Al}$ were detected in one or more water sample analysed in this study. The concentration of $\mathrm{Tl}$, $\mathrm{Pb}, \mathrm{Al}, \mathrm{Cr}, \mathrm{Mn}, \mathrm{Co}, \mathrm{Ni}, \mathrm{Cu}, \mathrm{Zn}, \mathrm{Mo}, \mathrm{Ag}$, and $\mathrm{Cd}$ in the five wells analysed in this study were ranged from: 0.02 $0.12,0.0-1.35,0.28$ - 30.11, 0.07 - 1.77, 0.02 - 8.96, $0.03-0.06,0.13-4.62,0.52-16.11,0.0-16.36,0.38-$ 8.75, $0.0-0.03$, and $0.0-0.04 \mathrm{ug} / \mathrm{L}$, respectively, see Table 1. Results showed that the concentration of ninetrace metals (Cr, Mn, Ni, Cu, $\mathrm{Zn}, \mathrm{Mo}, \mathrm{Pb}, \mathrm{Cd}$, and $\mathrm{Al}$ ) is within the allowed WHO limits in drinking water (50, 500, 20, 2000, 3000, 70, 10, 3, and $200 \mathrm{ug} / \mathrm{L}$, respectively), however six metals of them (Cr, Mn, Ni, Cu, Mo, and $\mathrm{Al}$ ) were detected in $100 \%$ of the samples, while $\mathrm{Pb}$, $\mathrm{Cd}$, and $\mathrm{Zn}$ were detected in $80 \%, 60 \%$, and $20 \%$ of the samples, respectively. In general, $82 \%$ of all samples analysed contained one or more of the 12 metals studied each in varying concentration.

There is no limit for Ag in drinking water according to WHO, however it is usually found in drinking water in the range of $5-50 \mathrm{ug} / \mathrm{L}$. Our results showed that all samples are within this limit. Co has also no limits in drinking water by WHO. However, this metal was detected in $100 \%$ of the water samples analysed in this study. Thallium ( $\mathrm{Tl})$ is a highly toxic element that humans are exposed to mainly by consumption of drinking water and vegetables grown in soil with high thallium content but also through inhalation of particles in the air. 
Table 1. Trace metals concentrations which are detected in the groundwater samples analyzed in this study (minimum, maximum, average, standard deviation (SD), and relative standard deviation (RSD)), as well as their WHO limits, and \% of the samples that found to contain particular heavy metal.

\begin{tabular}{|c|c|c|c|c|c|c|c|c|c|c|c|}
\hline \multirow[t]{2}{*}{ concentration (ppb) } & \multicolumn{11}{|c|}{ Heavy metal } \\
\hline & $\mathrm{Cr}$ & $\mathrm{Mn}$ & Co & $\mathrm{Ni}$ & $\mathrm{Cu}$ & $\mathrm{Zn}$ & Mo & $\mathrm{Ag}$ & $\mathrm{Cd}$ & $\mathrm{Pb}$ & $\mathrm{Bi}$ \\
\hline Minimum & 22.6 & 4.56 & 0.34 & 9.15 & 21.93 & 22.19 & 0.0 & 0.0 & 0.0 & 12.94 & 1.33 \\
\hline Maximum & 165.5 & 552.3 & 4.93 & 87.28 & 925.5 & 302.98 & 6.17 & 149.7 & 2.19 & 486.4 & 96.52 \\
\hline Average & 56.1 & 112.6 & 3.16 & 26.7 & 143.6 & 111.8 & 11.3 & 39.7 & 1.17 & 45.8 & 32.8 \\
\hline SD & 6.1 & 11.8 & 1.5 & 4.1 & 36.3 & 29.7 & 3.6 & 13.7 & 0.8 & 14.3 & 14.1 \\
\hline RSD (\%) & 10.9 & 10.5 & 47.5 & 15.4 & 25.2 & 26.6 & 31.9 & 34.5 & 68.3 & 31.2 & 43.0 \\
\hline $\begin{array}{l}\% \text { of samples that } \\
\text { found to contain that } \\
\text { heavy metal }\end{array}$ & 100 & 100 & 100 & 100 & 100 & 100 & 37 & 18 & 38 & 100 & 100 \\
\hline Limits & 50 & 500 & No limits & 20 & 2000 & 3000 & 70 & No limits ${ }^{*}$ & 3 & 10 & $\begin{array}{l}\text { No } \\
\text { limits }\end{array}$ \\
\hline $\begin{array}{l}\% \text { of samples that } \\
\text { exceeded the limit }\end{array}$ & 59 & 4.5 & / & 34 & 0 & 0 & 0 & $\begin{array}{l}4.5 \text { (exceeded } \\
50 \mathrm{ppb})\end{array}$ & 0 & 100 & \\
\hline
\end{tabular}

*usually found in concentration of 5 - $50 \mathrm{ppb}$.

Thallium is also present in fossil fuels, alloys, and in electronic utilities. The increasing use of the element and emissions from notably energy production has lead to a higher load on the surface of the Earth. The allowed WHO limits of $\mathrm{Tl}$ in water is 0.01 - $1 \mathrm{ug} / \mathrm{L}$ (IPCS, 1996). Our results showed that $\mathrm{Tl}$ is detected in $100 \%$ of the water samples analysed with a range of $0.02-0.12 \mathrm{ug} / \mathrm{L}$, which indicates that such concentration level of $\mathrm{Tl}$ would be harmful to human being consuming this groundwater.

A one way ANOVA statistical test was used to test if the concentration of the analysed metals is significantly different between the five groundwater wells. Results showed that the five wells in this study are different from each other at 95\% confidence level in terms of trace metal content. These findings confirm locational variations of the metals in the wells analysed in this study.

\subsection{Sources of Heavy Metals in the Groundwater Samples}

Heavy metals exist in water in colloidal, particulate and dissolved phases [28] with their occurrence in water bodies being either of natural origin (e.g. eroded minerals within sediments, leaching of ore deposits and volcanism extruded products) or of anthropogenic origin (i.e. solid waste disposal, industrial or domestic effluents) [3]. The most common metals that humans are exposed to are Aluminium, Arsenic, Cadmium, Lead and Mercury. Aluminium has been associated with Alzheimer's and Parkinson's disease, senility and presenile dementia. Arsenic exposure can cause among other illness or symptoms cancer, abdominal pain and skin lesions. Cadmium exposure produces kidney damage and hypertension. Lead is a commutative poison and a possible human car- cinogen [29].

The quality of groundwater sources are affected by the characteristics of the media through which the water passes to the ground water zone of saturation [30], thus, the heavy metals discharged by industries, traffic, municipal wastes, hazardous waste sites as well as from fertilizers for agricultural purposes and accidental oil spillages from tankers can result in a steady rise in contamination of ground water [31]. Additionally, groundwater quality is influenced considerably by the quality of the recharge source. Variations in natural and human activities reflect spatial variations of the aquifer and the hydro chemical parameters of the groundwater. Pollution sources are classified as point sources and diffuse sources. Point sources are sources that can be clearly identified and pinpointed (such as landfill leachate). Diffuse sources cannot be pinpointed and are distributed over a large surface area (application of fertilizers and pesticides in agriculture).

In Palestine, groundwater is one of the major sources of water. Efficient management of this resource requires a good understanding of its status. Groundwater management in the West bank is affected by the randomly distributed dumping sites, solid waste landfills, cesspits, especially in rural communities, as well as agricultural and industrial practices. Accordingly, the shallow aquifer in the eastern and western groundwater basins is deteriorated; high concentrations of nitrate and sulphate were detected larger than the WHO standards. Microorganisms were detected in some springs inside rural communities in Ramallah area [20,21]. This could be reflected on the water supply for these communities for the fact that these water sources are the major sources for drinking and agricultural purposes [21]. 
In West Bank and especially in rural areas, people dispose their wastewater using cesspits which is one of the main pollution sources to groundwater. Most of these cesspits are emptied by vacuum tankers and disposed into wadis or to improper dumping sites. These dumping sites are located in agricultural lands and their sites were selected randomly without any consideration to the soil characteristics, topography and climate as well as groundwater. As none of the existing dumping sites is designed to collect leachate from solid waste degradation, the leachate always finds its way through the soil to the groundwater, increasing concentration of pollutants including heavy metals to the water. In addition to municipal wastes and cesspits, urban, agricultural and industrial activities in the study area may also contribute to the contamination of the groundwater with heavy metals $[20,21]$. Our recommendations are that uncontrolled disposal of wastes and incineration of solid waste should be banned and responsible authorities have to monitor and control the quality of groundwater periodically (e.g. heavy metals content) in West Bank as this water is used for drinking especially in regions suffering from water scarcity.

\section{Conclusion}

Groundwater from North West Bank contains eleven heavy metals ( $\mathrm{Tl}, \mathrm{Pb}, \mathrm{Cr}, \mathrm{Mn}, \mathrm{Co}, \mathrm{Ni}, \mathrm{Cu}, \mathrm{Zn}, \mathrm{Mo}, \mathrm{Ag}$, and $\mathrm{Cd}$ ) and one metal (Al) in $82 \%$ of samples analysed from five wells, with nine trace metals $(\mathrm{Cr}, \mathrm{Mn}, \mathrm{Ni}, \mathrm{Cu}$, $\mathrm{Zn}, \mathrm{Mo}, \mathrm{Pb}, \mathrm{Cd}$, and $\mathrm{Al}$ ) is within the allowed WHO limits in drinking water. However, six metals of them (Cr, $\mathrm{Mn}, \mathrm{Ni}, \mathrm{Cu}, \mathrm{Mo}$, and $\mathrm{Al}$ ) were detected in $100 \%$ of the samples. Although Co has no limits in drinking water by WHO, this metal was detected in $100 \%$ of the water samples analysed in this study. Thallium ( $\mathrm{Tl}$ ), a highly toxic element with a WHO limit of 0.01 - $1 \mathrm{ug} / \mathrm{L}$, is detected in $100 \%$ of the water samples analysed with a range of $0.02-0.12 \mathrm{ug} / \mathrm{L}$. It indicates that such concentration level of $\mathrm{Tl}$ would be harmful to the human being consuming this groundwater. There are locational variations in the concentration of metals in the wells analysed in this study.

\section{Acknowledgements}

The authors thank the German Research Foundation (Deutsche Forschungsgemeinschaft), DFG for their financial support through TRION project.

\section{REFERENCES}

[1] M. A. Momodu and C. A. Anyakora, "Heavy Metal Contamination of Ground Water: The Surulere Case Study.” Research Journal Environmental and Earth Sciences, Vol. 2, No. 1, 2010, pp. 39-43.
[2] J. K. Vodela, J. A. Renden, S. D. Lenz, W. H., MchelHenney and B. W. Kemppainen, "Drinking Water Contaminants,” Poultry Science, Vol. 76, 1997, pp. 14741492.

[3] J. E. Marcovecchio, S. E. Botte and R. H. Freije, "Heavy Metals, Major Metals, Trace Elements”. In: L. M. Nollet, Ed., Handbook of Water Analysis, 2nd Edition, CRC Press, London, 2007, pp. 275-311.

[4] A. T. Batayneh, "Heavy Metals in Water Springs of the Yarmouk Basin, North Jordan and Their Potentiality in Health Risk Assessment," International Journal of the Physical Sciences, Vol. 5, No. 7, 2010, pp. 997-1003.

[5] N. Abderahman and Y. Abu-Rukah, "An Assessment Study of Heavy Metal Distribution within Soil in Upper Course of Zarqa River Basin/Jordan,” Environmental Geology, Vol. 49, No. 8, 2006, pp. 1116-1124. http://dx.doi.org/10.1007/s00254-005-0154-4

[6] I. Adekunle, M. Adetunji, A. Gbadebo and O. Banjoko, "Assessment of Groundwater Quality in a Typical Rural Settlement in Southwest Nigeria,” International Journal of Environmental Research and Public Health, Vol. 4, No. 4, 2007, pp. 307-318. http://dx.doi.org/10.3390/ijerph200704040007

[7] D. J. Ferner, "Toxicity and Heavy Metals," eMedicine Journal, Vol. 2, No. 5, 2001, p. 1.

[8] H. Roberts, “Lead Poisoning,” 2013. http://www.setlet.com

[9] D. Dupler, “Heavy Metal Poisoning,” In: J. L. Longe, Ed., Gale Encyclopedia of Alternative Medicine, Gale Group, Farmington Hills, 2001, pp. 2054-2057.

[10] T. A. Laniyan, O. O. K. Phillips and L. Elesha "Hazards of Heavy Metal Contamination on the Ground-Water around a Municipal Dumpsite in Lagos, South-Western Nigeria,” International Journal of Engineering \& Technology, Vol. 11, No. 1, 2011, pp. 61-69.

[11] O. T. Oyeku and A. O. Eludoyin, "Heavy Metal Contamination of Groundwater Resources in a Nigerian Urban Settlement," African Journal of Environmental Science and Technology, Vol. 4, No. 4, 2010, pp. 201-214.

[12] O. Momot and B. Synzynys, “Toxic Aluminium and Heavy Metals in Groundwater of Middle Russia: Health Risk Assessment," International Journal of Environmental Research and Public Health, Vol. 2, No. 2, 2005, pp. 214-218. http://dx.doi.org/10.3390/ijerph2005020003

[13] M. A. Iqbal and S. G. Gupta, "Studies on Heavy Metal Ion Pollution of Ground Water Sources as an Effect of Municipal Solid Waste Dumping," African Journal of Basic \& Applied Sciences, Vol. 1, No. 5-6, 2009, pp. 117122.

[14] B. Rajappa, "Monitoring of Heavy Metal Concentration in Groundwater of Hakinaka Taluk, India," Contemporary Engineering Sciences, Vol. 3, No. 4, 2010, pp. 183190.

[15] R. Gutierrez, H. Rubio-Arias, R. Quintana, J. Ortega and M. Gutierrez, "Heavy Metals in Water of the San Pedro River in Chihuahua, Mexico and Its Potential Health Risk,” International Journal of Environmental Research and Public Health, Vol. 5, No. 2, 2008, pp. 91-98. 
http://dx.doi.org/10.3390/ijerph5020091

[16] D. Kar, P. Sur, S. Mandal, et al., “Assessment of Heavy Metal Pollution in Surface Water," International Journal of Environmental Science and Technology, Vol. 5, No. 4, 2008, pp. 119-124. http://dx.doi.org/10.1007/BF03326004

[17] C. Voica, M. H. Kovacs, A. Dehelean, D. Ristoiu and A. Iordache, "ICP-MS Determinations of Heavy Metals in Surface Waters from Transylvania," Romanian Journal of Physics, Vol. 57, No. 6-7, 2012, pp. 1184-1193.

[18] I. Ismail and I. Mat Saleh, "Analysis of Heavy Metals in Water and Fish (Tilapia sp.) Samples from Ttasik Mutiara, Puchong,” The Malaysian Journal of Analytical Sciences, Vol. 16, No. 3, 2012, pp. 346-352.

[19] UNEP, "Desk Study on the Environment in the Occupied Palestinian Territories," United Nations Environment Programme, Nairobi, 2003.

[20] M. Ghanem and N. Samhan, "Groundwater Pollution Assessment in Tulkarem Area, Palestine,” Journal of Earth Sciences and Geotechnical Engineering, Vol. 2, No. 4, 2012, pp. 1-16.

[21] M. Ghanem, S. Samhan, E. Carlier and A. Wasim, "Groundwater Pollution Due to Pesticides and Heavy Metals in North West Bank,” Journal of Environmental Protection, Vol. 2, No. 4, 2011, pp. 429-434. http://dx.doi.org/10.4236/jep.2011.24049

[22] Y. El-Nahhal, "Contamination of Groundwater with Heavy Metals in Gaza Strip,” 10th International Water Technology Conference, Alexandria, 23-25 March 2006, pp. 1139-1150. http://www.water-observatory.net/sources/iwtc2006/15-1. $\underline{\mathrm{PDF}}$

[23] A. Abed and S. Wishahi, "Geology of Palestine: The West Bank and Gaza Strip. Palestin,” Palestine Hydrology Group, Ramallah, 1999.

[24] PWA, "Data Review on the West Bank Aquifers,"
Working Report SUSMAQ-MOD \# 02 V2.0, Sustainable Management of the West Bank and Gaza Aquifers, Water Resources and Planning Department, Palestinian Water Authority, Palestine, 2001.

[25] D. J. Scarpa, "Eastward Groundwater Flow from the Mountain Aquifer,” In: J. Isaac and H. Shuval, Eds., Water for Peace in the Middle East, Elsevier Science Publications, Amsterdam, 1994, pp. 193-203.

[26] APHA (American Public Health Association), "Standard Methods for the Examination of Water and Wastewater," 20th Edition, Washington DC, 1998, p. 1294.

[27] WHO, “Total Dissolved Solids in Drinking Water," Background Document for Development of WHO Guidelines for Drinking Water Quality (WHO/SDE/WSH/03.04/ 16), 2003.

[28] A. A. Adepoju-Bello, O. O. Ojomolade, G. A. Ayoola and H. A. B. Coker, "Quantitative Analysis of Some Toxic Metals in Domestic Water Obtained from Lagos Metropolis," Nigerian Journal of Pharmacy, Vol. 42, No. 1, 2009, pp. 57-60.

[29] O. Adeyemi, O. B. Oloyede and A. T. Oladiji, "Physicochemical and Microbial Characteristics of Leachate Contaminated Ground Water,” Asian Journal of Biochemistry, Vol. 2, No. 5, 2007, pp. 343-348. http://dx.doi.org/10.3923/ajb.2007.343.348

[30] M. T. Bakare-Odunola, "Determination of Some Metallic Impurities Present in Soft Drinks Marketed In Nigeria,” The Nigerian Journal of Pharmaceutical Research, Vol. 4, No. 1, 2005, pp. 51-54.

[31] I. O. Igwilo, O. J. Afonne, U. J. Maduabuchi and O. E. Orisakwe, "Toxicological Study of the Anam River in Otuocha, Anambra State, Nigeria," Archives of Environmental \& Occupational Health, Vol. 61, No. 5, 2006, pp. 205-208. http://dx.doi.org/10.3200/AEOH.61.5.205-208 